\title{
Just a minute: incredible numbers at play at the macro and micro level
}

\section{Biji T. Kurien}

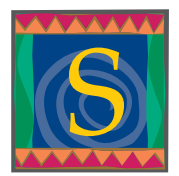

o much happens in 1 minute, at both the macro level (the Universe) and the micro level (within the human body).

In 1 minute, the Earth, weighing about 5.95 sextillion (1000 trillion) metric tonnes (roughly the equivalent of 1000 million metric tonnes per person living on Earth at present), travels about $1775 \mathrm{~km} / \mathrm{min}$ in its orbit around the Sun. Photons of light from the Sun blaze about 18 million $\mathrm{km}$ through space.

In this 1 minute, an average human heart contracts about 75 times, pumping 4-5 litres of blood through vessels ranging in thickness from the size of a forefinger to the width of a single hair. A colourful menagerie of about 35000 billion red blood cells, 50 billion white blood cells and 1500 billion platelets, salubriously swathed in ultra-rich liquid nutrient, travels through about 40000 million individual arteries, veins or capillaries for a combined distance of about $96000 \mathrm{~km}$ to reach the nethermost points of the body multiple times. During each visit, each red blood cell carries about 100 million oxygen molecules strapped onto about 25 million hemoglobin molecules in a collective effort to supply tissues with the oxygen needed for metabolism. A sturdy cock- tail of a couple of trillion antibody molecules completes a highly technical, and successful, surveillance of the entire system, tumbling along with the cellular constituents. Tragically, this 1 minute also sees the death of about 300 million cells. Fortunately, replacements arrive even as the cells die.

Specific gene segments, from an impressive array of about 25000 protein coding genes made from about 3 billion base pairs, carry out the processes of replication, transcription and translation within each of the 75 trillion cells of the body, with the exception of the mature red blood cells; the DNA from each of these 75 trillion cells, if stretched end to end, measures about 6 feet in length. During this minute about 60 million chemical reactions take place just in the ribosomes alone, assembling in the thousands around the endoplasmic reticulum and leading to the synthesis of about 120000 protein molecules.

Air sweeps in and out of the 370 million or so alveoli present in the lungs, with a combined interior area of about $80 \mathrm{~m}^{2}$, about 25 times. Each time air rushes in, it passes over the olfactory epithelium, located on the roof of the 2 nasal passages and innervated with about 10 million olfactory sensory receptors. Meanwhile, a sub-

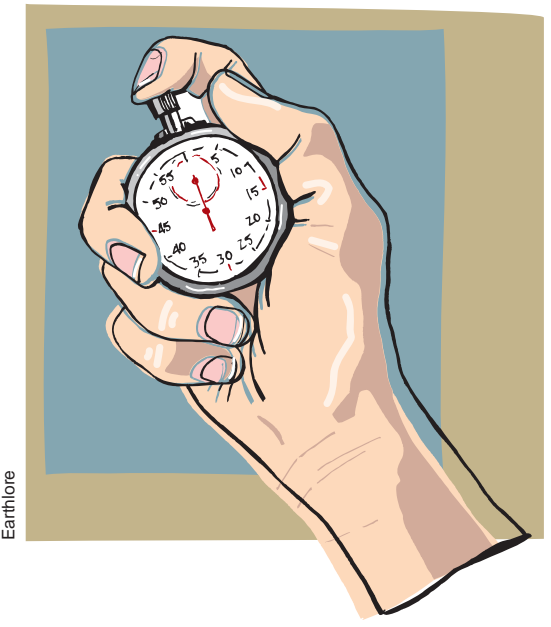

stantial portion of the 100 millionstrong neurons of the brain have orchestrated everything, coordinating all movements and thoughts by communicating with one another and with other parts of the body, using a significant portion of the 100 trillion synapses found in the entire brain.

The fact that all this happens in 1 minute is nothing short of a miracle. The Earth moves around without any commotion. The human body works far too quietly for all the complexities inherent within itself. The numbers at play baffle the mind.

Biji Kurien is Senior Research Scientist at the Oklahoma Medical Research Foundation, Arthritis and Immunology, Oklahoma City, Okla. 